\title{
In vitro antiplasmodial activity and toxicity assessment of plant extracts used in traditional malaria therapy in the Lake Victoria Region
}

\author{
Teresa Akeng'a Ayuko' ${ }^{+}$, Richard Njihia Njau², Wanjala Cornelius ${ }^{1}$, Nyangasi Leah ${ }^{2}$, \\ Isiah Omollo Ndiege ${ }^{3}$ \\ 'Department of Applied Chemistry, Kigali Institute of Science and Technology, BP 3900 Kigali, Rwanda ²Department of Chemistry, Jomo \\ Kenyatta University of Agriculture and Technology, Nairobi, Kenya ${ }^{3}$ Department of Chemistry, School of Pure and Applied Sciences, \\ Kenyatta University, Nairobi, Kenya
}

As part of our program screening the flora of the Lake Victoria Region, a total of 54 organic extracts from seven plant families (8 species) were individually tested for antiplasmodial activity against chloroquine-sensitive [Sierra Leone (D-6)] and chloroquine-resistant [Vietnam (W-2)] strains. Only 22\% of these extracts exhibited very high in vitro antiplasmodial activity. Six methanol (MeOH) extracts and one chloroform extract showed in vitro antiplasmodial activity against the D-6 Plasmodium falciparum strain, while only three $\mathrm{MeOH}$ extracts were active against the $W-2$ strain. All of the ethyl acetate extracts proved to be inactive against both strains of $\mathrm{P}$. falciparum. A brine shrimp cytotoxicity assay was used to predict the potential toxicity of the extracts. The cytotoxicity to antiplasmodial ratios for the $\mathrm{MeOH}$ extracts were found to be greater than 100, which could indicate that the extracts are of low toxicity.

Key words: antiplasmodial - cytotoxicity - plant extracts - malaria therapy

Eighty percent of the world's population uses herbal remedies (Zirihi et al. 2005). There are several plants that have been used by people living around the Lake Victoria Basin, a malaria endemic zone, to manage and treat malaria (Gachathi 1989, Kokwaro 1993). There is a need to carry out systematic investigations using modern scientific methods to establish the efficacy and toxicity of the medicinal plants commonly used by traditional medical practitioners. Thus, organic extracts from eight plants used by local indigenous communities in the Lake Victoria Region for traditional malaria therapy, namely Microglossa pyrifolia (Lam.) Kuntze, Kigelia africana (Lam.) Benth, Lippia javanica (Burm F.) Spreng, Carissa edulis (Forssk) Vahl., Maytenus heterophylla, (Eckl. \& Zeyh.) Strychnos henningnsii (Gilc.), Strychnos usambarensis (Gilc.) and Periploca linearifolia (Dill and Rich), were studied in regard to their antiplasmodial activity and were evaluated for toxicity against brine shrimp larvae (Artemia salina).

\section{MATERIALS AND METHODS}

Plant collection - The plant materials (Table I) were collected from the Lake Victoria Basin in Nyanza Province, Kenya, in May 2003. Their selection was based on documented literature and interviews with local communities (Kokwaro 1993). The plant specimens were

Financial support: SIDA, VICRES, IUCEA

+Corresponding author: tezakenga@yahoo.co.uk

Received 2 December 2008

Accepted 28 July 2009 identified by S.G. Mathenge of the University of Nairobi Herbarium, where voucher specimens were deposited. The samples were cut into small pieces and air-dried in the shade for two weeksand then ground into a fine powder using a motorised laboratory grinding mill (Christy and Norris Ltd, Chelmsford, England).

Extraction - All of the solvents used were of analytical grade. For each sample of ground plant material (100 $\mathrm{g}$ ), sequential cold extractions were performed for $72 \mathrm{~h}$ using hexane, chloroform $\left(\mathrm{CHCl}_{3}\right)$, ethyl acetate (EtOAc) and methanol $(\mathrm{MeOH})$. The extracts were decanted and filtered through Whatman filter paperand the resulting filtrates were dried under reduced pressure $\left(40^{\circ} \mathrm{C}\right)$. The percentage yield for each sample was determined and the crude extracts were stored in a freezer at $-4^{\circ} \mathrm{C}$.

Preparation of drugs - Stock solutions of the crude extracts $(10 \mathrm{~mL}, 250 \mu \mathrm{g} / \mathrm{mL})$ were made with sterile de-ionised water and filtered through 0.45 and $0.22 \mu \mathrm{m}$ micro-filters in a laminar flow hood. The water insoluble extracts were first dissolved in dimethylsulphoxide (DMSO) (solvent concentration $<0.025 \%$ ) (Elueze et al. 1996) and then sonicated until a homogeneous solution was obtained. Stock solutions of the reference drug [chloroquine (CQ) sulphate salt, purity $>99 \%$, SigmaAldrich Kenya Ltd] were similarly prepared in sterile water. All of the drugs were stored under refrigeration.

Cultures of Plasmodium falciparum - Two laboratory adapted $P$. falciparum cultures, D-6 (CQ-sensitive from Sierra Leone) and W-2 (CQ-resistant from Vietnam) were used in the study. The strains were cultured and maintained at the Walter Reed Malaria Research Laboratories at the Kenya Medical Research Institute (KEMRI), Nairobi. The culture medium was a variation of that de- 
TABLE I

Medicinal plants from the Lake Victoria Region used to treat malaria

\begin{tabular}{|c|c|c|c|c|}
\hline Plant family & $\begin{array}{l}\text { Species } \\
\text { (voucher) }\end{array}$ & Vernacular name & Location of collection & Plant parts used \\
\hline Apocynaceae & $\begin{array}{c}\text { Carissa edulis } \\
\text { (Forssk) Vahl (2004/22) }\end{array}$ & Ochuoga & Ratanga-Karungu Road & Stem bark \\
\hline Asclepiadacae & $\begin{array}{l}\text { Periploca linearifolia } \\
\text { (Dill \& Rich) }(2004 / 26)\end{array}$ & Awayo & Rachuonyo & Stem bark \\
\hline Bignoniaceae & $\begin{array}{c}\text { Kigelia africana } \\
\text { (Lam.) Benth }(2004 / 23)\end{array}$ & Yago & Got Ramogi & Leaves \\
\hline Celastraceae & $\begin{array}{l}\text { Maytenus heterophylla } \\
\text { (Eckl. \& Zeyh.) }(2004 / 20)\end{array}$ & Akudho & Suba & Root bark \\
\hline Compositae (Asteracceae) & $\begin{array}{l}\text { Microglossa pyrifolia } \\
\text { (Lam.) Kuntze }(2004 / 21)\end{array}$ & Nyabung-Odide & Mirogi River Bank & Leaves \\
\hline \multirow[t]{2}{*}{ Strychnaceae } & $\begin{array}{l}\text { Strychnos usambarensis } \\
\text { (Gilc.) }(2004 / 25)\end{array}$ & Mpilipili & Homabay & Root bark \\
\hline & $\begin{array}{l}\text { Strychnos henningnsii } \\
\text { (Gilc.) }(2004 / 24)\end{array}$ & Umnono & Migori & Root bark \\
\hline Verbenaceae & $\begin{array}{c}\text { Lippia javanica } \\
\text { (Burm F.) }(2004 / 19)\end{array}$ & Ang'awe-Rao & Rongo-Migori Road & Roots \\
\hline
\end{tabular}

scribed by Trager and Jensen (1976), which consisted of RPMI 12640 supplemented with 10\% human serum, 25 $\mathrm{mM} \mathrm{N}$-2- hydroxyethylpiperazine- $N$-2-ethanesulfonic acid and $25 \mathrm{mM} \mathrm{NaHCO}$. Human type $\mathrm{O}^{+}$erythrocytes served as host cells. The cultures were incubated at $37^{\circ} \mathrm{C}$ in an atmosphere of $3 \% \mathrm{CO}_{2}, 5 \% \mathrm{O}_{2}$ and $92 \% \mathrm{~N}_{2}$.

Antiplasmodial assay - The antiplasmodial assays were carried out at the Walter Reed Army Institute of Research laboratories based at KEMRI.

An in vitro semi-automated micro-dilution assay technique was used that measures the ability of the extracts to inhibit the incorporation of $\left[\mathrm{G}^{-}{ }^{3} \mathrm{H}\right]$ hypoxanthine into the malaria parasite (Desjardins et al. 1979, O'Neill et al. 1985).

Aliquots of the culture medium $(25 \mu \mathrm{L})$ were added to all the wells of a 96-well flat-bottomed micro-culture plate (Costar Glass Works, Cambridge, UK). The test solutions $(25 \mu \mathrm{L})$ were added in duplicate to the first wellsand a Titertek motorised hand diluter (Flow Laboratories, Uxbridge, UK) was used to make two-fold serial dilutions of each sample over a 64-fold concentration range. The susceptibility tests were carried out with an initial $200 \mu \mathrm{L}$ of parasite culture $(0.4 \%$ parasitaemia, $1.5 \%$ haematocrit $)$ in each well. The stock solutions of the plant extracts were diluted in the plate to give a $100 \mu \mathrm{g} / \mathrm{mL}$ concentration (as the highest concentration) and then diluted two-fold until reaching a concentration of $1.56 \mu \mathrm{g} / \mathrm{mL}$. A suspension $(200 \mu \mathrm{L}, 1.5 \% \mathrm{v} / \mathrm{v})$ of parasitised erythrocytes $(0.4 \%$ parasitaemia) in the culture medium was added to all the test wells. Non-parasitised erythrocytes were used in control experiments. The plates were incubated at $37^{\circ} \mathrm{C}$ in an atmosphere of $3 \% \mathrm{CO}_{2}, 5 \% \mathrm{O}_{2}$ and $92 \% \mathrm{~N}_{2}$. After $48 \mathrm{~h}$ each well was pulsed with $25 \mu \mathrm{L}$ of culture medium containing $0.5 \mu \mathrm{Ci}$ of $\left[\mathrm{G}-{ }^{3} \mathrm{H}\right]$-hypoxanthineand the plates were incubated for a further $18 \mathrm{~h}$. The contents of each plate were harvested onto glass fibre filters, washed thor- oughly with distilled water, dried and the radioactivity measured using a Betaplate ${ }^{\mathrm{TM}}$ liquid scintillation counter (Wallac, Zurich, Switzerland).

Data from the counter was imported into a Microsoft Excel spreadsheet, which was then transferred into an Oracle database programme to determine $\mathrm{IC}_{50}$ values. A minimum of three separate determinations was carried out for each sample.

Brine shrimp toxicity (BST) assay - BST assays were carried out on the $\mathrm{MeOH}$ extracts that showed good antiplasmodial activity. The brine shrimp ( $A$. salina) toxicity bioassay was conducted according to McLaughlin et al. (1991). Artificial seawater was prepared by dissolving sea salt $(38.0 \mathrm{~g})$ in $1 \mathrm{~L}$ of distilled water. The seawater was put in a small tank and a teaspoon of brine shrimp eggs was added to the covered half of a divided tank. The other side was not covered so as to allow light in that attracted the hatched shrimps. The tank containing the brine shrimp eggs was left at RT for $48 \mathrm{~h}$ to allow the eggs to hatch. Samples of the extracts were dissolved in DMSO and diluted with artificial seawater so that the final concentration of DMSO did not exceed $0.05 \%$. Different concentrations $(2000,1000,500,400,200,100,50 \mu \mathrm{g} / \mathrm{mL})$ of the $\mathrm{MeOH}$ extracts were prepared, in triplicate, in test tubes. The test tubes used were washed and sterilised in an autoclave. Brine shrimp larvae (nauplii, 10) were added to each tube. All the test tubes were covered at RT for $24 \mathrm{~h}$. After this period, the number of dead and surviving brine shrimps was recorded. Each experiment was replicated three timesand the average values were determined. The toxicity of each extract was determined from $50 \%$ lethal concentration values determined by probit analysis (Solis et al. 1993). Emetine chloride (98\% purity, Sigma-Aldrich Kenya Ltd) was used as a positive control. 


\section{RESULTS}

Table I lists the plants that were identified as being used in the treatment and management of malaria-related fevers. The table includes the plants' family, species, voucher number, parts used, local names and the exact location of the sampling.

The results of the in vitro antiplasmodial tests are summarised in Table II. Two strains of Plasmodium were used, a CQ-sensitive strain and a CQ-resistant strain. CQ was used as a positive control. The activities of the crude extracts were grouped according to Deharo et al. (2001). Thus, any extracts that showed an $\mathrm{IC}_{50}$ for antiplasmodial activity of less than $5 \mu \mathrm{gmL}^{-1}$ were considered active, while those that had $\mathrm{IC}_{50}$ 's from 5-10 $\mu \mathrm{gmL}^{-1}$ were considered moderately activeand those extracts with $\mathrm{IC}_{50}$ 's of over $10 \mu \mathrm{gmL}^{-1}$ were considered inactive.

The activities obtained indicate that there are differences in the strains' sensitivities to the extracts. The hydrophilic $\mathrm{MeOH}$ extracts of P. linearifolia, M. pyrifolia and L. javanica showed high anti-parasitic activity against both strains of $P$. falciparum. However, the methanolic extract from $S$. henningnsii was active against the CQ-sensitive strain and inactive against the CQ-resistant strain of $P$. falciparum. The $\mathrm{CHCl}_{3}$ extracts from $M$. heterophylla had moderate activity towards both strains, but the $\mathrm{CHCl}_{3}$ extracts from $S$. henningnsii were only moderately active against the CQsensitive $P$. falciparum strain. All of the EtOAc extracts were inactive, as well as the extracts from the stem bark (SB) of $C$. edulis. The methanolic extracts from this specie's root bark (RB) were moderately active against the D-6 strain of $P$. falciparum, but were inactive against the $\mathrm{W}-2$ strain. It has been reported elsewhere that the methanolic extracts of $C$. edulis and S. henningnsii roots obtained from Central Kenya (Meru) have mild antiplasmodial activity against CQ-sensitive (ENT 30) and CQ-resistant (NF 50) strains of falciparum (Kirira et al. 2006).

Well-known traditional antimalarial plants like $K$. africana and $S$. usambarensis were found to be inactive in vitro. This phenomenon can be explained by several factors, such as the degradation of active compounds during storage or the presence of prodrugs that undergo enzymatic transformations in vivo to give active antiplasmodial compounds (Krettli et al. 2001).

During this study, it was not feasible to subject all the lipophilic hexane extracts to antiplasmodial assays. This was mainly due to low yields and insufficient quantities of reagents. The only hexane extract assayed was from L. javanica and that extract was found to be inactive.

The brine shrimp toxicity data and the calculated cytotoxicity to antiplasmodial ratios (CARs) are summarised in Table III. The methanolic extracts from the four plant species with the highest antiplasmodial activities were subjected to the BST assay. The methanolic extracts from these antiparasitic plants exhibited no significant toxicity. The $M$. pyrifolia extract was found to be the least toxic. Emetine hydrochloride, a standard antiparasitic therapy, was found to be more toxic to the shrimps than any of the methanolic plant extracts tested. However, further tests, like in vivo cytotoxicity measurements or in vitro tests with HeLa cells are needed to conclusively determine these extracts' CAR values.

\section{DISCUSSION}

During rational drug discovery from plant sources, in vitro and/or in vivo assays are carried out. In vitro assays are performed in order to determine the activity of the target molecules before toxicity studies in the real organism are performed. While in vivo tests are generally more practical, more rapid and less expensive than

TABLE II

Antiplasmodial activity $\left(\mathrm{IC}_{50} \mu \mathrm{g} / \mathrm{mL}\right)$ of plant extracts against chloroquine (CQ)-sensitive from Sierra Leone (D-6) and CQresistant from Vietnam (W-2) Plasmodium falciparum

\begin{tabular}{|c|c|c|c|c|c|c|}
\hline \multirow[b]{3}{*}{ Plant species } & \multicolumn{6}{|c|}{$\mathrm{IC}_{50} \pm \mathrm{SD}(\mu \mathrm{g} / \mathrm{mL})$} \\
\hline & \multicolumn{3}{|c|}{$\begin{array}{c}\text { CQ-sensitive } \\
\text { (D-6) }\end{array}$} & \multicolumn{3}{|c|}{$\begin{array}{l}\text { CQ-resistant } \\
(\mathrm{W}-2)\end{array}$} \\
\hline & $\mathrm{CHCl}_{3}$ & EtOAc & $\mathrm{MeOH}$ & $\mathrm{CHCl}_{3}$ & EtOAc & $\mathrm{MeOH}$ \\
\hline \multicolumn{7}{|l|}{ Carissa edulis } \\
\hline $\mathrm{RB}$ & $25.55 \pm 1.68$ & $22.92 \pm 2.93$ & $4.67 \pm 1.42$ & $41.15 \pm 2.40$ & $37.60 \pm 1.86$ & $19.50 \pm 1.19$ \\
\hline SB & $26.26 \pm 0.12$ & $26.37 \pm 0.66$ & $>50$ & $32.07 \pm 1.14$ & $24.61 \pm 0.93$ & $>50$ \\
\hline Periploca linearifolia & $8.65 \pm 1.73$ & $25.78 \pm 1.57$ & $1.60 \pm 0.01$ & $24.69 \pm 0.73$ & $36.13 \pm 1.87$ & $3.30 \pm 0.18$ \\
\hline Kigelia africana & $29.01 \pm 0.78$ & $13.50 \pm 0.04$ & $25.77 \pm 0.30$ & $34.79 \pm 0.94$ & $22.63 \pm 0.95$ & $27.84 \pm 1.29$ \\
\hline Maytenus heterophylla & $4.00 \pm 0.44$ & $18.95 \pm 0.10$ & $13.07 \pm 1.60$ & $5.56 \pm 0.78$ & $29.04 \pm 0.85$ & $19.53 \pm 4.40$ \\
\hline Microglossa pyrifolia & $23.59 \pm 0.85$ & $14.76 \pm 1.80$ & $1.59 \pm 0.07$ & $30.05 \pm 0.97$ & $25.03 \pm 0.51$ & $2.50 \pm 0.15$ \\
\hline Strychnos henningnsii & $5.35 \pm 1.32$ & $25.07 \pm 0.96$ & $1.07 \pm 0.07$ & $16.20 \pm 2.38$ & $37.43 \pm 0.96$ & $26.25 \pm 0.04$ \\
\hline Strychnos usambarensis & $10.58 \pm 2.90$ & $15.65 \pm 4.29$ & $23.82 \pm 1.36$ & $24.37 \pm 0.40$ & $24.00 \pm 2.20$ & $27.92 \pm 0.70$ \\
\hline Lippia javanica & $12.25 \pm 0.72$ & $12.12 \pm 0.79$ & $1.35 \pm 0.06$ & $18.59 \pm 0.26$ & $15.80 \pm 0.26$ & $1.75 \pm 0.17$ \\
\hline
\end{tabular}

$\mathrm{CQ}: \mathrm{IC}_{50}=0.024 \pm 0.002$ and $0.034 \pm 0.003$ for the $\mathrm{D}-6$ and $\mathrm{W}-2$ strains, respectively; $\mathrm{CHCl}_{3}$ : chloroform extract; $\mathrm{MeOH}$ : methanol extract; RB: root bark; SB: stem bark; tOAc: ethyl acetate extract. 


\section{TABLE III}

$\mathrm{LC}_{50}(\mu \mathrm{g} / \mathrm{mL})$ and cytotoxicity to antiplasmodial ratio (CAR) values of the most active methanolic plant extracts

\begin{tabular}{lccc}
\hline & & \multicolumn{2}{c}{ CAR } \\
\cline { 3 - 4 } Species & LC $_{50}$ & D-6 & W-2 \\
\hline Microglossa pyrifolia & $2367 \pm 3.67$ & 1578.0 & 946.8 \\
Lippia javanica & $1138 \pm 1.33$ & 843.0 & 650.3 \\
Strychnos henningnsii & $944.76 \pm 94.66$ & 822.2 & 36.0 \\
Periploca linearifolia & $370.85 \pm 52.76$ & 231.3 & 112.4 \\
\hline
\end{tabular}

emetine hydrochloride $\left(\mathrm{LC}_{50} 20.6 \pm 1.6\right)$ used as positive control. D-6: from Sierra Leone; W-2: from Vietnam.

in vitro cultures, not all anti-malarial drugs are active in the Plasmodium berghei mouse model (Ferreira-daCruz et al. 2000). Also, in vivo studies require significantly larger quantities of the potential therapeutic agent when compared to in vitro assays, such that about $1 \mathrm{~g}$ of extract is required per in vivo test (Krettli et al. 2001). The selection of plant species for the study (Table I) was based on ethnopharmacology and documented literature. Although a random selection of plants might have been used, this procedure was considered inadequate. Indeed, it has been reported that by employing a random selection, only $1 \%$ of plants among 300 randomly selected species were found to be active, while nearly $20 \%$ of about 50 plants selected in light of traditional knowledge were found to be active (Krettli et al. 2001).

There was a large variability in the activity of the crude extracts against $P$. falciparum (Table II). The distribution of active ingredients in any plant is uniqueand depends on the species, age, geographical variations and the specific plant tissue used. Traditional practitioners use different plant parts from each species according to their efficacy. However, the plant extracts investigated during this study can be largely classified into two groups. The first group includes all the extracts that showed a high activity $\left(\mathrm{IC}_{50}<10 \mu \mathrm{g} / \mathrm{mL}\right.$, Table II). This group of extracts $(22 \%)$ may be useful in the treatment of malaria and thus further purification and isolation of the active compounds from this group of extracts and their development into drugs should be explored. The second group of extracts has $\mathrm{IC}_{50}{ }^{\prime} \mathrm{s} \geq 20 \mu \mathrm{g} / \mathrm{mL}(56 \%)$. Additionally, there are a few borderline extracts with $\mathrm{IC}_{50}$ values $\geq 10 \mu \mathrm{g} / \mathrm{mL}$.

The activity values obtained in this study are comparable to those of known plant remedies of various origins (O' Neill 1987, MacKinnon et al. 1997, Kristina et al. 1999, Oketch-Rabah et al. 1999, Krettli et al. 2001, Bertani et al. 2005, Vigneron et al. 2005, Zirihi et al. 2005, Chikara et al. 2006, Kirira et al. 2006, Mesquita et al. 2007). For example, when studying the crude ethanolic extracts of Artemisia annua by our study's protocol, the $\mathrm{IC}_{50}$ value against the CQ-resistant $\mathrm{K}-1$ strain was found to be $3.9 \mu \mathrm{gmL}^{-1}$ (O' Neill et al. 1985).

The observed activities of the hydrophilic extracts are in contrast to those reported by Jenett-Siems et al. (1999), who found that lipophilic extracts were more active than hydrophilic extracts. Hydrophilic extracts are closer in composition to the aqueous preparations commonly used by traditional practitioners. François et al. (1996) have similarly investigated the organic extracts from the roots, $\mathrm{SB}$, fruit rind, seeds and leaves of plantsand found a wide range of activities with the highest activities being found in the methylene chloride root extracts.

Several classes of plant secondary metabolite are responsible for the observed anti-malarial activity, but the most important and diverse bio-potencies have been observed in alkaloids, quassinoids and sesquiterpene lactones (Quetin-Leclercq et al. 1991, Wright et al. 1994, Schwikkard \& van Heerden 2002, Saxena 2003). The plants investigated during this study belong to various families, from which similar metabolites have been isolated. For instance Andrade-Neto et al. (2007) isolated antiplasmodial indole alkaloids from plant species of the Apocynaceae family in the Brazilian Amazon.

Several phytochemical reports have been published concerning extracts from the four plants we found to be most active. The reports on these medicinal plants indicate that the plant species contain antiplasmodial metabolites. The antiplasmodial alkaloids isostrychnofoline $\left(\mathrm{IC}_{50} 1.2 \mu \mathrm{M}\right)$ and holstiine $\left(\mathrm{IC}_{50} 1.0 \mu \mathrm{M}\right)$ have been isolated from the RB of $S$. henningnsii Strychnaceae (Frederich et al. 1999, 2002). Most plants from the Celastraceae family contain a class of sesquiterpene nicotinoyl alkaloids, which are characterised by a dihydroagarofuran sesquiterpene bonded as a diester to a substituted nicotinic acid (Schaneberg et al. 2001). $1 \beta$-Acetoxy- $9 \alpha$-benzoyloxy- $2 \beta, 6 \alpha$-dinicotinoyloxy- $\beta$ dihydroagarofuran and $\beta$-amyrin have been isolated from M. heterophylla (Orabi et al. 2001). The leaf extracts from $P$. linearifolia, in the family Asclepiadacae, contain phytin, anthraquinone, gemnamagenin, gymnemic acid II, betaine, cholin and lupeol (Nagaraju \& Rao 1990, Hichri et al. 2002). Additionally, M. pyrifolia, Compositae (Asteraceae), leaves have been reported to contain several terpenoids, such as E-phytol, 1,3- hydroxyoctadeca-9Z, 11E, 15-trien oic acid and 6E-geranylgeraniol-19 oic acid, which exhibit antiplasmodial $\mathrm{IC}_{50}$ values between $2.5-13.7 \mu \mathrm{g} / \mathrm{mL}$ (Köhler et al. 2002). The reported data on $L$. javanica (Verbenaceae) indicates that there are several terpenoids isolated from the flowering tops of this species. These terpenoids exhibit larvicidal, antimalarial, spasmolitic, sedative, hypotensive and anti-inflammatory activities (Pascual et al. 2001, Omolo et al. 2004). However, there is no phytochemical data reported on root extracts from L. javanica.

The CAR was very high for most of the extracts tested. These CAR values are comparable to those reported for CQ (518.27) on HeLa cells after $72 \mathrm{~h}$ (Yapi et al. 2000). This may indicate the selectivity of these extracts because the extracts exhibit weak toxicity and good CAR values (Munoz et al. 1999). However, several reports demonstrate that the antimalarial activity of a compound and its toxicity are not directly related (O’Neill et al. 1987, Schwikkard \& van Heerden 2002, Kirira et al. 2006). There are reports that certain other 
plant species' methanolic extracts exhibit significant toxicity in the brine shrimp assay (Mohtasheen et al. 2001, Kirira et al. 2006).

In conclusion, only $22 \%$ of the 54 organic extracts from plants used in traditional malaria therapies in the Lake Victoria Region showed high antiplasmodial activity. Methanolic extracts from several species were found to exhibit high antiplasmodial activityand low toxicity toward test organisms. In this study a shrimp assay was used for toxicity evaluation, we recommend that further toxicity tests be conducted on HeLa cell lines under conditions similar to the antiplasmodial test in order to better determine these extracts CAR values.

\section{ACKNOWLEDGEMENTS}

To the Kenya Medical Research Institute (KEMRI) and US Army Walter Reed Research Institute, for allowing us to use their laboratory equipment, and to the technical support from Liyala Pamela and Akala Hosea.

\section{REFERENCES}

Andrade-Neto VF, Pohlit AM, Pinto ACS, Silva ECC, Nogueira KL, Melo MRS, Henrique MC, Amorim RCN, Silva LFR, Costa MRF, Nunomura RCS, Nunomura SM, Alecrim WD, Alecrim MGC, Chaves FCM, Vieira PPR 2007. In vitro inhibition of Plasmodium falciparum by substances isolated from Amazonian antimalarial plants. Mem Inst Oswaldo Cruz 102: 359-366.

Bertani S, Bourdy G, Landau I, Robinson JC, Esterre P, Deharo E 2005. Evaluation of French Guiana traditional antimalarial remedies. J Ethnopharmacol 98: 45-54.

Chikara I, Kiyohara H, Soonthornchareonnon N, Chuakul W, Ishiyama A, Sekiguchi H, Namatame M, Otoguro K, Omuro S, Yamada H 2006. Antimalarial activity of biflavonoids from Ochna integerrima. Plant Med 72: 611-614.

Deharo E, Bourdy G, Quenevo C, Munoz V, Ruiz G, Sauvain M 2001. A search for natural bioactive compounds in Bolivia through multidisciplinary approach. Part V. Evaluation of the antimalarial activity of plants used by the Tacana Indians. J Ethnopharmacol 77: 91-98.

Desjadins RE, Canfield CJ, Haynes JD, Chulay JD 1979. Quantitative assessment of antimalarial activity in vitro by semi-automated microdilution technique. Antimicrob Agents Chemother 16: 710-718.

Elueze EI, Croft SL, Warhust DC 1996. Activity of pyronaridine and mepacrine against 12 strains of Plasmodium falciparum in vitro. $J$ Antimicrob Agents Chemother 37: 511-518.

Ferreira-da-Cruz MF, Adami YL, Espínola-Mendes EC, Figueiredo MR, Daniel-Ribeiro CT 2000. The intraperitoneal Plasmodium berghei-Pasteur infection of swiss mice in not a system that is able to detect the antiplasmodial activity in the Pothomorphe plant extracts that are used as antimalarials in Brazilian endemic areas. Exp Parasitol 94: 243-247.

François G, Assi L, Holenz J, Bringmann G 1996. Constituents of Picralima nitida display pronounced inhibitory activities against asexual erythrocytic forms of Plasmodium falciparum in vitro. J Ethnopharmacol 54: 113-117.

Frederich M, Jacquier MJ, Thepenier P, De Mol P, Tits M, Philippe G, Delaude C, Angenot L, Zeches-Hanrot M 2002. Anti-plasmodial activity of alkaloids from various Strychnos species. J Nat Prod 65: 1381-1386.
Frederich M, Tits J, Hayette MP, Brandt V, Penelle J, Llabres G, Angenot L 1999. 10'-Hydroxyusambarensine, a new bisindole alkaloid from the roots of Strychnos usambarensis. J Nat Prod 62: 619-621.

Gachathi FN 1989. Kikuyu botanical dictionary of plant names and uses, AMREF, Nairobi, $52 \mathrm{pp}$.

Hichri F, Hammouda O, Jannet HB, Migri Z, Abreu PM 2002. Terpenoids from the fruit barks of Periplocca laevigata growing in Tunisia. J Soc Chimie Tun 4: 1565-1568.

Jenett-Siems K, Mockenhaupt FP, Bienzle U, Gupta MP, Eich E 1999. In vitro antiplasmodial activity of Central American medicinal plants. Trop Med 4: 611-615.

Kirira PG, Rukunga G, Wanyonyi AW, Muregi FM, Githirwa JW, Muthaura CN, Omar SA, Tolo F, Mungai GM, Ndiege IO 2006. Anti-plasmodial activity and toxicity of extracts of plants used in traditional malaria therapy in Meru and Kilifi Districts of Kenya. J Ethnopharmacol 106: 403-407.

Köhlera I, Jenett-Siems K, Krafta C, Abbiw C, Bienzled U, Eicha E 2002. Herbal remedies traditionally used against malaria in Ghana: bioassay guided fractionation of M. pyrifolia (Asteraceae). Z Naturfosch 57c: 1022-1027.

Kokwaro JO 1993. Medicinal plants of East Africa, Kenya Literature Bureau, Nairobi, 20 pp.

Krettli AU, Andrade-Neto VF, Brandão LM, Ferrari WMS 2001. The search for new antimalarial drugs from plants used to treat fever and malaria or plants ramdomly selected: A review. Mem Inst Oswaldo Cruz 96: 1033-1042.

Kristina JS, Frank P, Mockenhaupt P, Ulrich B, Mahabir P, Gupta G, Eckart E 1999. In vitro antiplasmodial activity of Central American medicinal plants. Trop Med Int Health 4: 611-615.

MacKinnon S, Durst T, Arnason JT 1997. Antimalarial activity of tropical Meliaceae extracts and gedunin derivatives. J Nat Prod 60: 336-341.

McLaughlin JL, Chang CJ, Smith DL 1991. Bench-top bioassays for the discovery of bioactive natural products: an update. In A Rahman, Studies in natural product chemistry, Elsevier, Amsterdam, p. 383-409.

Mesquita ML, Grellier P, Mambu L, de Paula JE, Espindola LS 2007. In vitro antiplasmodial activity of Brazilian Cerrado plants used as traditional remedies. J Ethnopharmacol 110: 165-170.

Mohtasheem M, Ahmed SW, Azhar I, Ali MS 2001. Brine shrimp bioassay of phoenix sylvestris. J Pharm Sci 14: 19-21.

Munoz V, Sauvain M, Mollinedo P, Callapa J, Rojas I, Gimenez A, Valentin A, Mallie M 1999. Antimalarial activity and cytotoxicity of (-)-Roemredine isolated from the stem bark of Sparattanthelium amazonum. Planta Medica 65: 448-449.

Nagaraju N, Rao KN 1990. A survey of plant crude drugs of Rayalaseema, Andhra Pradesh, India. J Ethnonopharmacol 29: $137-158$.

Oketch-Rabah HA, Dossaji SF, Mberu EK 1999. Antimalarial activity of some Kenyan medicinal plants. Pharm Biol 37: 329-334.

O’Neill MJ, Bray DH, Boardmann P, Chan KL, Phillipson JD, Warhust JD, Peters W 1987. Plants as a source of anti-malarial drugs. Part 4. Activity of Brucea javanica fruits against chloroquine resistant $P$. falciparum in vitro and against $P$. berghei in vivo. $J$ Nat Prod 50: 41-48.

O’Neill MJ, Bray DH, Boardmann P, Phillipson JD, Warhurst DC 1985. Plants as sources of antimalarial drugs. Part 1. In vitro test method for the evaluation of crude extracts from plants. Planta Med 51: 394-398. 
Omolo MO, Okinyo D, Ndiege O, Lwande W, Hassanali A 2004. Repellency of essential oils of some Kenyan plants against Anopheles gambiae. Phytochemistry 65: 2797-2802.

Orabi KY, Al-Qasoumi SI, El-Olemy MM, Mossa JS, Muhammad I 2001. Dihydroagarofuran alkaloid and triterpenes from Maytenus heterophylla and Maytenus arbutifolia. Phytochemistry 58: 475-480.

Pascual ME, Slowing K, Carretero E, Sánchez MD, Villar A 2001. Lippia: traditional uses, chemistry and pharmacology: a review. J Ethnopharmacol 76: 201-204.

Quetin-Leclerq J, Tits M, Angenot L, Bisset G 1991. Alkaloids from Strychnos usambarensis stem bark. Planta Med 57: 501-502.

Saxena S, Pant N, Jain DC, Bhakuni RS 2003. Antimalarial agents from plant sources: a review. Curr Sci 85: 1314-1329.

Schaneberg BT, Green DK, Sneden AT 2001. Dihydroagarofuran sesquiterpene alkaloids from Maytenus putterlickoides. J Nat Prod 64: 624-626.

Schwikkard S, van Heerden FR 2002. Review on antimalarial activity of plant metabolites. Nat Prod Rep 19: 675-692.
Solis PN, Colin WW, Margaret MA, Gupta MP, Phillipson JD 1993. A micro-well cytotoxicity assay using Artemia salina (Brine shrimp). Planta Med 59: 250-252.

Trager W, Jensen JB 1976. Human malaria parasites in continuous culture. Science 193: 673-675.

Vigneron M, Deparis X, Deharo E, Bourdy G 2005. Antimalarial remedies in French Guiana: a knowledge attitudes and practices study. J Ethnopharmacol 98: 351-360.

Wright CW, Allen D, Cai Y, Chen Z, Phillipson JD, Warhurst D, Angenot O 1994. Selective anti-protozoal activity of some Strychnos alkaloids. Phytother Res 8: 149-152.

Yapi AD, Mustofa M, Valentin A, Chavignon O, Teulade J, Mallie M 2000. New potential antimalarial agents: synthesis and biological activities of original diaza-analogs of phenanthrene. Chem Pharm Bull 48: 1886-1889.

Zirihi GN, Mamb L, Gu'ed'e-Guina F, Bodo B, Grellier P 2005. In vitro antiplasmodial and cytotoxicity of 33 West African plants used for treatment of malaria. J Ethnopharmacol 98: 281-285. 